\title{
GREEN INFRASTRUCTURE ON THE MEDITERRANEAN VALENCIAN COAST
}

\author{
JOSÉ LUIS MIRALLES I GARCIA \\ Department of Urban Planning, Polytechnic University of Valencia, Spain.
}

\begin{abstract}
During the period from 1997 to 2007 on the Spanish Mediterranean coast, a large urban sprawl developed, caused partly by the increase in economic activity and population and partly by the increased tourism on the coast. This expansion produced mass tourism processes at risk of landscape degradation phenomena and end-of-life-cycle of tourism activities, following the guidelines known as the case of La Manga. This expansion also produced many programmed and planned urban development initiatives, which have not been implemented. In the case of Valencia, on the ground, which has already urbanized but not yet built upon, could be built up to 125,000 homes. From 2007, because of the hugely excessive supply of houses, construction and all new developments in the Valencian coast are in a state of paralysis. Paradoxically, the security crisis in the Arab Mediterranean countries has resulted in the growth of tourism on the Spanish Mediterranean coast, particularly in Valencia. This situation could, however, be temporary. Therefore, at present, a change is evident in the model of tourism to achieve a high quality of landscape and tourism services and to avoid mass tourism. At present, in 2015, the regional government is promoting a plan to identify and preserve the green infrastructure of the Valencian coast. It has approved a moratorium on new urban development across the coastal strip to a distance of 500 meters from the sea. This paper explains the approaches, objectives and expected results of this initiative.

Keywords: coastal tourism, green infrastructure, regional planning.
\end{abstract}

\section{INTRODUCTION}

Tourism is a very important activity in Spain. Similarly to other countries, its origin is very old; however, we can say that, in Spain, current tourism started in 1959 with the opening of Spain's borders to foreign exchanges. Since then tourism has been based on urban development of second homes, hotels, tourism services and associated activities. This model has long been the dominant paradigm. In about 1975, a new paradigm was introduced: the environmental paradigm. Since that time, there has been gradual questioning of boundless coastal urbanization for tourism and, simultaneously, of tourism activities based on continuous coastal urban development.

However, the number of tourists continued to increase until 2007 (Fig. 1), when the economic crisis began. Simultaneously, signs of exhaustion of the model are becoming clearer and the overcrowding of the coast is becoming more intense. For example, the EGATUR report of 2004 [1] states that "Tourists who demonstrate little satisfaction with their visit are those who spend the most per person and person per day". That is, surveys suggest that those tourists, who spend more, do not satisfy their expectations of quality.

Other tourism destinations compete with Spain and offer less urbanized landscapes, for example on the Mediterranean coast of Arabian countries. In spite of this, in recent years, the number of tourists visiting Spain has grown again. Maybe safety problems in these countries explain the changing trend in Spain.

This paper is part of the Proceedings of the $7^{\text {th }}$ International Conference on Sustainable Tourism (Sustainable Tourism 2016)

www.witconferences.com 


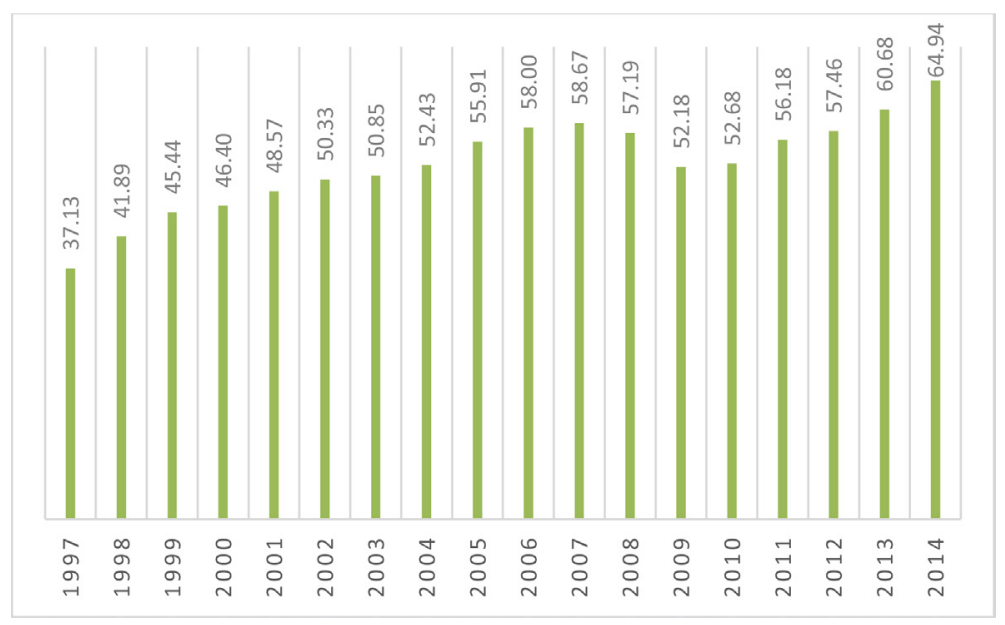

Figure 1: Tourists in Spain (millions per year). Source: FRONTUR [2].

In any case, signs of exhaustion of the model are clear. Thus, some stakeholders, such as a Valencian regional government, are introducing policies oriented to stop urban development and promote quality for coastal landscapes as a part of the new paradigm.

\section{URBANIZATION PROCESS ON SPANISH MEDITERRANEAN COAST}

The urbanization process on the Spanish Mediterranean coast has been very intense in the period from 1959 to the present, state García-Ayllón [3] or Miralles \& García-Ayllón [4].

For example, in the Valencian region, a large part of the coast has been developed by the building of houses as second homes. Now in Spain, according to Miralles [5, 6], second homes account for about $30 \%$ of total housing, while, in the Valencian region, they account for about $37 \%$. According to the classic model, the tourist industry promotes urban development for tourist activities: accommodation (houses, hotels and apartments), services, shops, stores, etc. In addition to tourism, most economic activity is concentrated on the coast. According to the Territorial Strategy of the Valencian Community [7], in 2006, based on Corine Land Cover data:

- $46.1 \%$ of the Valencian coast has an artificial surface

- $31.5 \%$ of the Valencian coast comprises agricultural zones

- $18.6 \%$ of the Valencian coast consists of forest zones or natural spaces

- $3.8 \%$ of the Valencian coast is formed of wetlands or water surface.

In Spain, particularly in Valencia, all urban development is planned. Every municipality has its urban plan, which defines the already developed lands (urban land), the lands suitable for urbanization (urbanizable lands) and lands not for urbanization (not urbanizable lands). The latter can be protected or common land.

Right at present, on the strip of the first 500 meters of coastline, according to the data of the Territorial Information System of Generalitat Valenciana [8], we have planned:

- 89.275 square kilometers of urban land (of these, 1.028 square kilometers correspond to urban heritage) 
- 50.859 square kilometers of urbanizable land

- 88.310 square kilometers of not urbanizable land:

- Common land, 16.237 square kilometers

- Public domain, 3.277 square kilometers

- Public facilities, 4.049 square kilometers

- Protected areas, 64.682 square kilometers

- Others, 0.064 square kilometers

- 228.444 square kilometers, TOTAL strip surface

Or rather, it is planned a very big surface to urban development. Also, according to the law, municipalities can change not urbanizable common land to urbanizable land. Therefore, the sum of the already developed land and planned urban development accounts for $61.3 \%$ of the coast.

\section{TOURISM ON SPANISH MEDITERRANEAN COAST}

In Spain, tourism's contribution is important, as can be seen in Table 1. The contribution to employment is also shown. In 2010, tourism contributed 10.2\% to the Spanish GDP. However, the regions of the Canaries and the Balearic Islands represent a very high contribution and show a significant economic dependence of this sector.

In 2014, Spain received 64,849 million tourists. Of these, 43,672 million, $67.25 \%$, went to regions of Mediterranean coast (Catalonia, Balearic Islands, Valencian Country, Murcia and Andalucía). Catalonia received 25.9\% of tourist, Balearic Islands 17.5\%, Andalucía 13.1\%, Valencian Country $9.6 \%$ and Murcia $1.2 \%$.

The data are similar in recent years. For example, the contribution made by tourism to economic activity in the Valencian region in 2008 [10]is estimated at:

- $13.0 \%$ of total GDP (13,845 million Euros).

- $12.8 \%$ of total EMPLOYMENT (294,679 jobs)

- $6.5 \%$ of total investment (2,139 million Euros of Gross Capital Formation-Investment).

- $5.2 \%$ of public spending (983 million Euros of public spending).

In 2015, the average daily spend per tourist in Spain was about 120 euros. Fig. 2 shows the distribution of regions in Spain and their average daily spend per person.

Table 1: Contribution of tourism to GDP and employment in 2010 for Spain and different regions. Source: IMPACTUR [9].

\begin{tabular}{lcc}
\hline & GDP $(\%)$ & Employment $(\%)$ \\
\hline Valencian Country & 12.6 & 13.4 \\
Andalusia & 12.5 & 11.9 \\
Canary Islands & 27.8 & 32.8 \\
Region of Madrid & 6.3 & 5.9 \\
Galicia & 10.6 & 11.5 \\
Balearic Islands & 43.2 & 30.3 \\
Spain & 10.2 & 7.3 \\
\hline
\end{tabular}




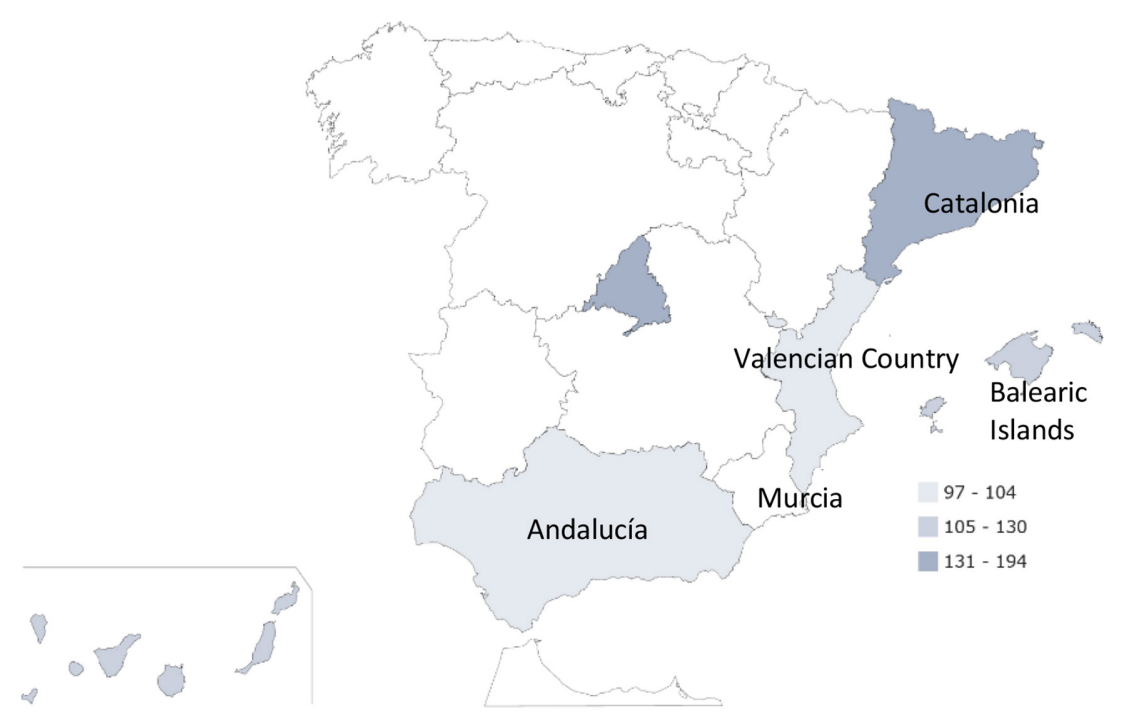

Figure 2: Average daily spending per tourist (euros per tourist per day) for different regions of Spain, 2015. Source: INE [11].

An important issue to consider is the type of activity that tourists engage in during their stay. For the Valencian region [12], the percentages of Spanish tourists involved in the main activities are:

- About $75 \%$ of Spanish tourists: go to the beach

- About 70\%: gastronomy and shopping

- About $45 \%$ : cultural visits, country walks and visiting family or friends

- About 35\%: night leisure

- About $15 \%$ : cultural shows and sports

- Less than 10\%: theme parks, nautical sports, etc.

In the case of foreign tourists, the main activities carried out are:

- About $70 \%$ of foreign tourists: go shopping

- About 40\%: fun/night leisure and cultural visits

- About 20\%: visiting family or friends

- About $10 \%$ : theme parks, cultural activities, gastronomy, cultural shows and sports.

- Less than 10\%: nautical sports, spa, golf and others.

\section{TOURISM MODEL CHANGE}

In Spain, the classic model of the tourism industry was based on:

- Build close to the beach for tourist accommodation (apartments, hotels, campsites, others)

- Build new facilities and infrastructures for tourists

- Tourist numbers grow year by year 
However, the continuous increase in the number of tourists and in urban tourism produces, in the long term, negatives impacts:

- disappearance or degradation of valuable natural areas

- disappearance or degradation of peri-urban agricultural areas

- widespread growth of tourist activities and services

The current tourism model in Spain began at 1959, an action planned as part of the Economic Stabilization Plan approved in the same year. Initially, according to the economic and social values of the time, the development of urban tourism was planned without limits. Gradually, the problems of mass tourism became evident.

The case of La Manga of the Mar Menor is paradigmatic. The case has been studied by Garcia-Ayllón [13], Miralles \& García-Ayllón [14] and García-Ayllón \& Miralles [15] and shows the evolution of the urban zone as a tourist product, from initial expansion to final degradation. As this is an urban area in a limited space and almost completely urbanized, urban renewal needed to solve the problems of degradation is very expensive.

The case of La Manga allows us to anticipate the evolution of the tourist industry when a process of excess widespread growth occurs. Many authors, such as Gaja [17], have warned of the need to change the model to avoid excessive widespread growth and the consequent decline in tourism. He means finding a level of equilibrium in the number of tourists and avoiding continued growth.

On the other hand, the excess of coastal urban development produces more problems. Many uses are made of and concentrated in coastal zones: cities, ports, natural landscapes, agricultural zones, etc. Natura 2000 Network involves 36\% the Valencia region's territory, an important part of which is located on the coast. As stated above, 64.682 square kilometers, representing a 500-meter strip of land running next to the sea, are declared protected areas.

Agricultural areas are also concentrated on the coast. In Fig. 3 the more important agricultural areas in the Valencian region can be seen. Because of the climate, if water is available, agricultural areas have a high level of productivity.

Consequently, there is a conflict of uses on the coast between general urban development, natural spaces, agricultural zones and tourist urban development. General and tourist urban development can produce environmental impacts; see Miralles, Díaz \& Altur [18].

Conflict of uses occurs more intensely on the peri-urban edges. It is of note that capital gains generated by the urban development are much greater than those generated by natural areas or agricultural uses. The dynamics of these situations are complex, as can be seen in Miralles [19], García-Ayllón [20] and Temes \& Moya [21]. In fact, development can be nonsustainable, according to Miralles [22].

For a long time, regional governments tried territorial management systems to promote simultaneously the urban development and the protection of natural resources, see Miralles [23], but without success. In fact, during the period from 1997 to 2007 in Valencia, there was a big real estate bubble, followed by a large economic crisis lasting until the present time. In this period, sometimes, if necessary, the protection was changed to allow the urban development.

As suggested by Miralles \& Gaja [24] or Panuccio, Amodeo, D’Agostino, Lamari \& Scattarreggia [25], it is necessary to change the model of urban development and orient the interventions in the existing city. That is, satisfy the needs of new urban uses, not through new urban expansions but through interventions of urban renewal in the existing city. 


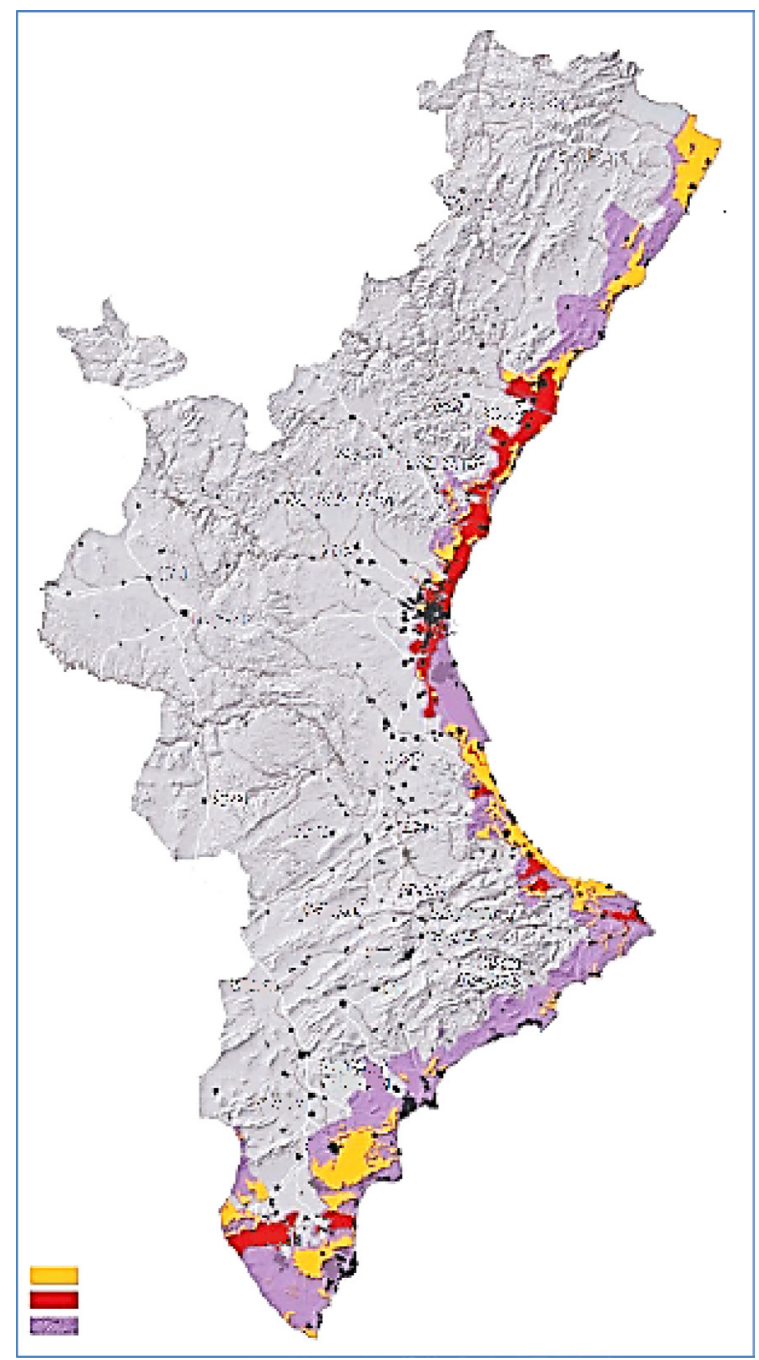

Figure 3: Agricultural areas on Valencian coast: top quality (red), average quality (yellow) and other lands (purple). Source: GVA [16].

\section{GREEN INFRASTRUCTURE FOR THE COAST}

In a communication from the Commission to the European Parliament, COM (2013) 249 final, Green Infrastructure (GI) - Enhancing Europe's Natural Capital [26], green infrastructure is defined as a strategically planned network of natural and semi-natural areas with other environmental features designed and managed to deliver a wide range of ecosystem services. It incorporates green spaces (or blue if aquatic ecosystems are concerned) and other physical features in terrestrial (including coastal) and marine areas. On land, GI is present in rural and urban settings.

The regional government of Valencia developed this concept in the last law about urban and regional planning, specifically in the Regional and Urban Planning and Landscape Act of 2014 [27]. 
In 2015, the regional government decided to plan the green infrastructures on the Valencian coast. Thus, he began the elaboration of Territorial Action Plan of Green Infrastructure of the Coast by the publication of the Initial Document of Strategic Environmental Assessment [17].

The plan aims for defining the green infrastructure in the 500-meter strip of land next to the Mediterranean Sea. In fact, this means defining or projecting the coastal landscape and, if necessary, changing the classification of the land from urbanizable (land planned for an urban destination) to not urbanizable (land planned to rural uses which, in Spain, can be protected or not protected). The objectives of this action are two. On the one hand, to identify current rural areas which must be protected (in this case we can consider these areas as a protected natural capital) and to design coast landscape (particularly identify essential elements of landscape and the main points of observation to maintain quality). On the other hand to stop the urbanization projects that can have negative environmental impacts or landscape impacts.

In November 2015, a moratorium on new urban development on the coast was approved for the duration of 1 year, while the plan is being elaborated. All this means, in fact, a real paradigm shift in the tourism model. For the first time, the planning of green infrastructure is a precondition to any other kind of planning.

\section{CONCLUSIONS}

Current tourism development in Spain started in 1959. The initial tourism model was based on growth in the number of tourists and urban development to meet the demands of accommodation, facilities, services and activities. This model has produced excessive urban development of the coast and overcrowding.

From about 1975, consideration began of a new paradigm that aimed to stabilize the number of visitors and promote the quality of the landscape and services as a way to maintain the attraction.

In the Valencian region, there have been attempts to harmonize tourism growth with environmental protection, but these have not managed to curb excessive urban development of the coast.

The new European policy on green infrastructure definitely promotes the paradigm shift. For the first time, in 2015, the regional government of Valencia promoted a plan to define green infrastructure on the Valencian coast as a way to improve the landscape and stop new urban tourism developments. This fact confirms the paradigm shift in the Valencian region.

\section{REFERENCES}

[1] Encuesta de Gasto Turístico (EGATUR), año 2004. Instituto de Estudios Turísticos, Ministerio de Industria, Turismo y Comercio, p. 62, available at www.iet.tourspain.es

[2] FRONTUR, available at http://estadisticas.tourspain.es/en-EN/Paginas/default.aspx

[3] García-Ayllón, S., Retrospective analysis of urban development in the Spanish Mediterranean Coast. WIT Transactions on Ecology and the Environment, 179, pp. 291-302, 2013. http://dx.doi.org/10.2495/SC130251

[4] Miralles, J.L. \& García-Ayllón, S., GIS analysis of the consequences of short-term urban planning in a mass tourism destination in Spain. International Journal of Sustainable Development and Planning, 10, (4), pp. 499-519, 2015.

http://dx.doi.org/10.2495/SDP-V10-N4-499-519 
[5] Miralles i Garcia, J.L., El darrer cicle immobiliari al País Valencià. O el progrés de la misèria, Fundació Nexe: València, 2014.

[6] Miralles i Garcia, J.L., Real estate crisis and sustainability in Spain. WIT Transactions on Ecology and Environment, 150, pp. 123-133, 2011.

http://dx.doi.org/10.2495/SDP110111

[7] Estrategia Territorial de la Comunidad Valenciana, Conselleria d'Habitatge, Obres Públiques i Vertebració del Territori. Generalitat Valenciana, available at www.citma. gva.es/va/web/planificacion-territorial-e-infraestructura-verde/trabajos-previos-76797

[8] Sistema d'Informació Territorial, Conselleria d'Habitatge, Obres Públiques i Vertebració del Territori. Generalitat Valenciana, available at www.citma.gva.es/ca/web/ sistema-de-informacion-territorial

[9] IMPACTUR Comunitat Valenciana 2010, Generalitat Valenciana, available at www. exceltur.org/impactur/

[10] Tourism in the Region of Valencia 2009, Conselleria de Turisme, Generalitat Valenciana, available at www.turisme.gva.es/opencms/opencms/turisme/es/contents/estadistiquesdeturisme/anuario/turismo/turismo_cv.html

[11] INE, Statistics National Institute, available at www.ine.es/inebmenu/mnu_hosteleria. htm

[12] Perfil del turista que visita la Comunidad Valenciana 2014, Generalitat Valenciana, available at www.turisme.gva.es/opencms/opencms/turisme/es/contents/estadistiquesdeturisme/anuario/perfil_turista/perfil_turista.html

[13] García-Ayllón, S. En los procesos de urbanización del mediterráneo: el caso La Manga. PhD thesis, Politechnic University of Valencia (Spain), 2013.

[14] Miralles, J.L. \& García-Ayllón, S., The economic sustainability in urban planning: case La Manga. WIT Transactions on Ecology and the Environment, 173, pp. 279-290, 2013.

http://dx.doi.org/10.2495/SDP130231

[15] García-Ayllón, S. \& Miralles, J.L., The environmental impacts of land transformation in the coastal perimeter of the Mar Menor lagoon (Spain). International Journal of Design \& Nature and Ecodynamics, 9(2), pp. 109-128, 2014. http://dx.doi.org/10.2495/DNE-V9-N2-109-128

[16] Initial Document of Strategic Environmental Assessment for Territorial Action Plan of Coast Green Infrastructure, Generalitat Valenciana, 2015, available at www.citma.gva. es/web/planificacion-territorial-e-infraestructura-verde/planes-de-accion-territorial

[17] Gaja i Díaz, F., Hyper planning and the construction bubble on the northern coast of the Valencian countryside (or how the unwarranted scenarios of planning have contributed to the present urban disaster). WIT Transactions on Ecology and the Environment, 192, pp. 207-217, 2015.

http://dx.doi.org/10.2495/ECO150191

[18] Miralles i Garcia, J.L., Díaz Aguirre, S. \& Altur Grau, V., Environmental impact on the Mediterranean Spanish coast produced by the latest process of urban development. WIT Transactions on Ecology and the Environment, 155, pp. 379-389, 2012. http://dx.doi.org/10.2495/SC120321

[19] Miralles i Garcia, J.L., The planning of Peri-Urban agricultural areas: the case of L'Horta de Valencia. Proc. of REAL CORP 2013. Planning Times, eds. M. Schrenk, V. Popovich, P. Zeile \& P. Elisei, Rome, pp. 953-962, 2013. 
[20] Garcia-Ayllon, S., Occupation models in peri-urban areas: actions for orchard-city integration. WIT Transactions on Ecology and the Environment, 192, pp. 111-122, 2015. http://dx.doi.org/10.2495/ECO150111

[21] Temes, R. \& Moya, A., Dynamics of change in the peri-urban landscape of Huerta de Valencia: the case of La Punta (Valencia). WIT Transactions on Ecology and the Environment, 192, pp. 123-131, 2015.

http://dx.doi.org/10.2495/ECO150121

[22] Miralles i Garcia, J.L., Urban coastal development in Valencian country: a paradigmatic case of non-sustainable development. International Journal of Sustainable Development and Planning, 10(3), pp. 301-314, 2015.

http://dx.doi.org/10.2495/SDP-V10-N3-301-314

[23] Miralles i Garcia, J.L., Sustainability regulations in urban planning: the experience of the autonomous community of Valencia (Spain). WIT Transactions on Ecology and the Environment, 120, pp. 3-12, 2009.

http://dx.doi.org/10.2495/SDP090011

[24] Miralles i Garcia, J.L. \& Gaja i Díaz, F., Proposal for a Natural Capital Bank as a managing tool for urban management sustainability. WIT Transactions on Ecology and the Environment, 54, pp. 477-486, 2002.

[25] Panuccio, P., Amodeo, L., D’ Agostino, P., Lamari, D. \& Scattarreggia T., Urban regeneration and Smart city according to EU strategies: an urban distribution center in city logistics. WIT Transactions on the Built Environment, 146, pp. 313-324, 2015. http://dx.doi.org/10.2495/UT150251

[26] European Commission, available at http://ec.europa.eu/environment/nature/ecosystems/index_en.htm

[27] Llei 5/2014 d'Ordenació del Territorio, Urbanisme i Paisatge de la Comunitat Valenciana, available at www.citma.gva.es/ca/web/planificacion-territorial-e-infraestructuraverde 